\title{
Description of Elementary Teacher Education Program's Student: Mapping Indonesian Language Competence for Prospective Teacher
}

\author{
Asrial, Syahrial, Dwi Agus Kurniawan, Nur Amalina, May Subandiyo \\ Faculty of Teaching and Education, Jambi University, Indonesia
}

How to cite this paper: Asrial, Syahrial, Kurniawan, D.A., Amalina, N. \& Subandiyo, M. (2018). Description of Elementary Teacher Education Program's Student: Mapping Indonesian Language Competence for Prospective Teacher. The Educational Review, USA, 3(2), 21-27.

http://dx.doi.org/10.26855/er.2019.02.001

*Corresponding author: Dwi Agus Kurniawan, Profesional Lecture, Faculty of Teaching and Education, Jambi University, Jambi, Indonesia.

\begin{abstract}
Pedagogic competence is the ability that must be possessed by a teacher in managing learners learn from planning execution and evaluation. In pedagogic competence, one of which must be improved by a prospective teacher is language competence. Indonesian is used as the medium of instruction in education. In the curriculum of primary, secondary and higher education must include the language. The importance of Indonesian language competence is well controlled by the students because the future teacher students will be able to establish good communication between students and teachers as well as have a good mastery of language structure and grammar. This research uses descriptive quantitative research design. The purpose of this study is to describe the students of the Faculty of Teacher Training and Education of Jambi University. A total of 340 students at elementary school teacher education Faculty of Teacher Training and Education program Jambi University participated in the study. The instrument used in this research is the test. The form of test used is a multiple choice with 4 choices and the number of questions about 32 questions. The test is used to measure students' competence on Indonesian competence and Pedagogic Competence. The results showed that the pedagogic competence of the students at elementary school teacher education program of Faculty of Teacher Training and Education of Jambi University was categorized as bad. This is because the number of students at elementary school teacher education program of Faculty of Teacher Training and Education of Jambi University in the category is not good as much as 254 students or $74.71 \%$. The competence of the language was in the good category. In the language competence, the students at elementary school teacher education program of Faculty of Teacher Training and Education of Jambi University have competence in a good category that is total 160 students and percentage $47.05 \%$.
\end{abstract}

\section{Keywords}

Language competence, Pedagogic competence, Prospective teacher

\section{Introduction}

Language is a medium for people to communicate and there are many languages in the world. Haryanto, et al; (2016) declare those languages have their own characteristics which make them different from one to another, including English. In addition to English, Indonesian is one of the national languages and official languages of the world. Cohn and Ravindranath (2014) state that Since independence, Indonesian has been increasingly ascendant to the language as well as coexisting alongside other native languages in the archipelago. There is a renewal of Indonesian vocabulary arranged in Big Indonesian Dictionary (KBBI). Smith (2009) states language use in the New Order is carefully monitored by teachers, language experts, and government officials who insisted that young people be trained in a 'proper and correct Indonesian'. KBBI can be used as an early reference by students and the general public in understanding the basic concepts from various fields of science.

One of the government's efforts to use the language is the existence of the policy of using the Indonesian language as the language of instruction in education. National language standards and their implementation through nation-building through 
the government (Smith, 2009). Law of the Republic of Indonesia Number 12 the year 2012 on Higher Education Article 37 paragraph (1) to regulate Indonesian language as the official language of the state shall be the language of instruction in Higher Education. Language education, especially at elementary school teacher education of Jambi University Faculty of Teacher Training and Education is important because it is a fundamental education in obtaining language for learners. Teachers should also learn to develop their techniques (Widiani et al, 2010)

Language is always closely related to grammar and communication skills. Choi and Sazawa (2016) claimed that language is a tool for communication and emphasizes the close Relationship between language and socio-cultural environments. Mastery of Indonesian language competence for prospective teachers can facilitate prospective teachers to communicate and teach and used in everyday life. Ibrahim (2001) dominating important functions (political, economic, academic, social, etc) in Indonesia society certainly can impose a barrier towards efforts in acquiring the English language. When a prospective teacher wants to become an Indonesian language teacher abroad this opportunity is very big because the Indonesian language is in striving as an ASEAN language. Andayani (2016) In the 32nd ASEAN Inter-Parliamentary Assembly (AIPA) in Phnom Penh, Cambodia, 2011, the Indonesian delegation fought for an important mission in fighting for Indonesian as ASEAN language, especially in AIPA meetings Indonesia was optimistic in fighting for Indonesian as the official language of Asian because most people in Asian are familiar with the Malay language. The importance of mastering language competence for prospective teachers, then a prospective teacher should always improve their competence.

Efforts to improve language competence can be done in various ways, one of which is the use of curriculum in Higher Education. Implementation of the curriculum at elementary school teacher education program Faculty of Teacher Training and Education of Jambi University contains Indonesian language learning. Students are required to follow the learning as much as 4 subjects namely 1 . Indonesian language that is aimed to prepare students who have competence in the material of Indonesian language that is the ability to write, read, hear, and speak; 2. improving Indonesian language skills in this subject again to discuss about 4 language competence that must be mastered is writing, reading, listening, talking; 3 . Indonesia language and literary education in elementary schools which aims to prepare students to have competence in teaching about children's literature starting from folklore, fairy tales, and other; 4. Model Learning Indonesian language is aimed at students have a good competence in learning in elementary school during teaching practice because it has understood various models of Learning. Of the 4 subjects taught are expected to improve pedagogical skills, especially in the ability of Indonesian language students Teachers Elementary School of the University of Jambi. Therefore, the competence of Indonesian language and pedagogic competence become the indicator of success improvement of the professional ability of a teacher.

The purpose of this study is to look at the pedagogic competence and language competence of elementary school teacher education students and their impact on prospective teachers and elementary school students. Questions in this study are as follows:

1. How to map Indonesian Competency in the elementary school teacher education program faculty of teacher training and education Jambi University?

2. What are the obstacles faced by students in learning indonesia in college?

3. How is the solution given in overcoming the obstacles students face in linguistic lectures?

\section{Method}

\subsection{Research Design}

This research uses quantitative research approach. According to Creswell (2009), quantitative research is a means for testing objective theories by examining the relationship between variables. The research design used in this research is descriptive quantitative research design. The research design was applied in the study: to describe primary school teacher education students knowledge of Indonesian language competence.

\subsection{Sample Research}

The population in this study was all elementary school teacher education students with a total of 550 students. The sample used as many as 340 studentsat elementary school teacher education program of Faculty of Teacher Training and Education of Jambi University participated in this study. The samples were designed and determined using a random sampling technique.

\subsection{Instruments and Procedures}

Data collection techniques used was tests and interviews. The form of the test used is multiple choices with 4 choices and the number of questions is 32 questions. This test is used to measure student competency in Indonesian language competence and Pedagogic Competence. Interviews were conducted with students in the education program of the Teacher Training and Education Faculty of the University of Jambi using structured interview techniques. The purpose of the interview is to obtain in-depth information related to competencies and the implementation that is taught. Data analysis in this study used descriptive statistics. Descriptive statistics used by researchers to describe sample data. Table number of questions are as follows. 
Table 1. Number of questions

\begin{tabular}{cll}
\hline NO & Test & Amount \\
\hline 1 & Indonesian Competence & 12 items \\
2 & Pedagogic Competence & items \\
\hline
\end{tabular}

\section{Results}

The results showed that students at elementary school teacher education program of Faculty of Teacher Training and Education of Jambi University generally had pedagogical competencies with a percentage of $7.35 \%$ in the good category and $74.71 \%$ in the bad category and students had Indonesian language competence with $47.07 \%$ categories good and with a percentage of $41.17 \%$ a bad category.

Table 2. The results of the pedagogic competency test for students at elementary school teacher education program

\begin{tabular}{|l|l|l|l|c|}
\hline Dimension & Category & Score & Frequency & $\%$ \\
\hline Pedagogic Competence & Very good & $16-20$ & 0 & 0 \\
\hline & Good & $11-15$ & 25 & $7.35 \%$ \\
\hline & Less good & $6-10$ & 61 & $17.94 \%$ \\
\hline Indonesian Competence & Not good & $1-5$ & 254 & $74.71 \%$ \\
\hline & Gery good & $10-12$ & 20 & $5.89 \%$ \\
\hline & Less good & $4-6$ & 140 & $47.05 \%$ \\
\hline & Not very good & $1-3$ & 20 & $41.17 \%$ \\
\hline
\end{tabular}

The table above shows that the pedagogic competence of students at elementary school teacher education program of Faculty of Teacher Training and Education of Jambi University is categorized as bad. This is because the number of students at elementary school teacher education program of Faculty of Teacher Training and Education of Jambi University in the category is not good as much as 254 students or $74.71 \%$. While in the lessgood category consists of 61 students with a percentage of $17.94 \%$ and in the good category there are 25 students with the percentage of $7.35 \%$. Hereinafter, in very good category with $0 \%$ percentage.

In the language competence, the students at elementary school teacher education program of Faculty of Teacher Training and Education of Jambi University have competence in a good category that is total 160 students and percentage $47.05 \%$. The number of students who get very good category is 20 students with a percentage of $5.89 \%$. While in the less good category that is 140 students with percentage $41.17 \%$. In the bad category, there are 20 students with a percentage of $5.89 \%$.

Interview results to clarify quantitative data can be translated as follows:

1. Good category: I enjoy studying at the elementary school teacher education program of Jambi University Faculty of Teacher Training and Education because I studied diligently to get achievement in Indonesian Language Course. I try to finish the task on time but also see the quality. Lecturers of Indonesian Language courses can convey the material clearly and systematically in accordance with the lesson plan so I pay attention to the lecturers' explanation well and the value given in accordance with the capabilities possessed. (student interview May 17, 2018)

2. Bad Category: I am not happy to learn Indonesian because I do not have interest in learning Indonesian but rather leaning on science courses because the study of science subjects is often done a practicum. The tasks given by my lecturer do addition, in the course Indonesian language is not supported by the language laboratory facilities because the Indonesian laboratory facilities are not yet available so for facilities such as earphones, table, tape or VCD are not available at elementary school teacher education program of Jambi University Faculty of Teacher Training and Education. (student interview May 17, 2018) The above comments show that students have experience in language learning and the constraints experienced in the 
implementation of language learning.

\section{Constraints Faced in Implementing the Indonesian Language Education}

The results of the invention showed that respondents identified four constraints in the implementation of the Indonesian language education at elementary school teacher education program faculty of teacher training and education Jambi university (Table 3): lack of student motivation at elementary school teacher education program Faculty of Teacher (Faculty of Teacher, Faculty of Teacher, Faculty of Teacher, Faculty of Teacher Training and Education of Jambi University on Indonesian pedagogic competence (83.33\%), lack of student attitudes at elementary school teacher education program of Faculty of Teacher Training and Education of Jambi University on Indonesian pedagogic competence (83.33\%), lack of lecturer performance according to perceptions of students at elementary school teacher education of Jambi University Faculty of Teacher Training and Education program on Indonesian pedagogic competence (83.33\%) and lack of student satisfaction at elementary school teacher education program Faculty of Teacher Training and Education of Jambi Universityon Indonesian pedagogic competence.

Table 3. Constraints faced in Implementing the Indonesian language education

\begin{tabular}{lc}
\hline \multicolumn{1}{c}{ Statement } & Number of Respondents \\
\cline { 2 - 2 } & Students (n=30) \\
\hline $\begin{array}{l}\text { Student Motivation at elementary school teacher education } \\
\text { program Faculty of Teacher Training and Education of Jambi }\end{array}$ & $83.33 \%$ \\
University on Indonesian pedagogic competence & \\
The attitude of student education at elementary school teacher \\
education program Faculty of Teacher Training and Education \\
of Jambi University to the pedagogic competence of Indonesian \\
language
\end{tabular}

The table above is seen based on the category of less good and not good.

\section{Discussion and Recommendation}

Pedagogic competence is a capability teacher must have in managing learners learn from planning, implementation, and evaluation. In pedagogic competence, one of which must be improved by a prospective teacher is language competence. Law No. 20 of 2003 on National Education System Article 37 in paragraph (1) and paragraph (2) regulates the curriculum of primary and secondary education and universities shall contain the language. Çetin and Demiral (2012) The language is the most important tool for an individual in order to express himself and understand the life. With the competence of language especially Indonesian language, then a future teacher will be able to establish good communication between a student with the teacher and have mastery of language structure and grammar. Adi (2011) The priority for a language learner is to master the language structure, and in the learning process, the emphasis on the language of meaning as a lesser goal. Indrianti (2012) In the language learning context, the students think that it is necessary to develop their grammatical competence in order to be able to use the language as a means of communication. If the ability of students as prospective teachers have good language competence then it will be able to communicate well also to learners. This implies the importance of grammar learning in order to achieve a higher level of communication (Wong, 2012).

In general, the results of the study show that pedagogical competence in terms of language skills possessed by students at elementary school teacher education program of Faculty of Teacher Training and Education of Jambi University education is in the less good category. Of the 340 students who took the test, there were 20 students who entered the excellent category with a percentage of $5.89 \%$, while 160 students entered in the good category with a percentage of $47.05 \%$, then 140 students entered the unfavorable category with a percentage of $41.17 \%$. and the remaining 20 students entered the bad category with a percentage of $5.89 \%$. Based on the results obtained through multiple choice questions, it can be seen that the students' language competencies in the teacher training elementary school teacher education program and Jambi university education science are 
still not in accordance with the expected competencies. These results indicate that students' language knowledge competencies in the education program of the teacher training elementary school and Jambi University education are not maximal.

If a prospective teacher does not master language competence, then the impact will be felt by the students when the student becomes a teacher. Ongoing learning becomes ineffective and efficient. The effectiveness of learning can be reviewed from the process and learning outcomes. Watkins, et al (2002) Teaching-learning processes for effective learning is promoted by activity, with reflection and sense-making; collaboration for learning; learner responsibility for learning; learning about learning. The effectiveness of language learning in terms of the learning process is that if students have not mastered language skills then learners have no interest in learning activities. Andrini (2016) Learning effectiveness is usually measured by the level of achievement of the learners. The effectiveness of language learning in terms of learning outcomes is that if students have no interest in learning then he will have difficulty in learning the material, so that will have an impact on low learning outcomes. If students have an interest in learning activities then can be expected learners get good learning outcomes. In Elementary School, the competence of language consists of 4 skills that are reading, writing, listening, and speaking. Impact if students do not have the ability to read will affect students' grammar. According to Ortlieb (2013) states that "They read very litle and lack skills in effective word arrangement, show poor understanding skills, and have limited language and vocabulary. If learners do not master the skills of language then the students were not proficient in reading, writing, listening and speaking. Paris et al (2015) "The lack of student skills in listening, speaking, and writing will also contribute to the students' mastery of discourse inadequate". Thus pedagogical competence in terms of language is very important to be mastered by students as a prospective teacher.

Based on interview results, the constraints faced by students can be caused by several factors. The factor is the lack of student motivation during Indonesian language learning. Motivation consists of two types of intrinsic motivation and extrinsic motivation. In intrinsic motivation when learning Indonesian language courses, students are not very diligent in learning, but when the new exam will be held to study. When the deadline of the Indonesian language assignment, prospective students still can relax but still do. In overcoming obstacles that hinder the achievement of Indonesian language subjects student candidate teachers handle it in accordance with the state of the heart (mood). Student candidates prefer to discuss light and seemingly unimportant matters rather than discussing tasks. In any assignment of language subjects prospective teachers do not use or complement with images or other relevant visual media. For extrinsic motivation on learning Indonesian language, in doing the task of prospective student teachers more emphasis on the quick finish because of the influence of friends without importance to the quality of their duties. In addition, prospective students are more likely to work individually instead of discussing to add task perfection and will find a source that supports the lecture tasks if the lecturer asks for it. Furthermore, the attitude of students at the time of learning Indonesian, prospective students do not pay attention to the lecturer's explanation on the story material for the child because the prospective teacher does not have the ability in the literary material of children and lack of interest in language learning. When held the test of Indonesian Language and other subjects, the prospective teacher is more leverage in preparing the exam in the preferred subject because the student of the teacher candidate does not have interest in learning Indonesian but rather leaning on other subjects like science and social science. Students of the prospective teachers like the science course because the lecturers give the material by using the media that can attract the attention of the students and the material of plant and animal cells are held practicum. Student prospective teachers like the social science course because the social science material is close to everyday life and is a multidisciplinary science such as geography, economics, sociology, etc. In addition, by studying social science can make a person into a good society, moral, moral and ethical.

Performance explains the quality and quantity achieved by a workforce, in carrying out its duties and responsibilities. The performance of lecturers at elementary school teacher education of Jambi University Faculty of Teacher Training and Education has been classified well in the implementation, as evidenced by the related interviews about the preparation of lecturers in teaching such as the availability of lesson plan, timeliness, teaching methods and media used in teaching. But from the interviews there are still who do not like the way of teaching the lecturer as well as in the use of teaching methods in learning, the methods conveyed by the lecturer only use the method of group discussion that is given from the first meeting to convey with the final exam Semester so according to the student is too boring interspersed with varied methods. Xiaoa and Wilkins (2015) Successful learning typically require effective performance from both students and lecturers. Lecturers who are committed to good learning, and thinking about how to convey information and monitor student progress. The committed lecturer is more likely, therefore, to demonstrate superior work performance and attain higher student attainment. Samian and Noor (2012) to be an excellent lecturer, one should master the delivery techniques and establish good relation with the students. The reverse is also true, poor teaching delivery is regarded by the students as the main factor that contributes to poor performance.

The lack of satisfaction of students is more directed to the existing facilities on campus at elementary school teacher education program Faculty of Teacher Training and Education Jambi University is the lack of laboratory facilities of Indonesian language, for the Indonesian language laboratory room is available room that is written Indonesian language room but for the facility such as earphones, table divider, tape or VCD are not yet available at elementary school teacher education Jambi University Faculty of Teacher Training and Education program. Long et al (2014) Attaining student satisfaction is one of the most critical objectives in all institutions of higher learning. The institutions that fail, to do so will affect their student's reputation and 
acceptance, in the future disgruntled students may also affect their academic performance.

The lack of good responses of students to the performance of lecturers, based on the indicators of learning methods used by lecturers is a small group discussion and then the results are presented to a large group. The steps are (1) the lecturer divides the students into several small groups; (2) each group is given a task with the same material; (3) the result of a small group percentage to a large group; (4) after the presentation is opened the question and answer session of this method that does not change during learning. Thus making the student bored while studying, hope the lecturer can use teaching methods other than just using the method of discussion, lecturers can also use the lecture method, question, and answer, demonstration. In addition to the method of discussion, the 3 methods are suitable in applied in learning Indonesian. As for the completeness of facilities in the form of language room, along with completeness such as earphones, DVD, table that is not available can be immediately completed so that learning Indonesian language can be implemented in the laboratory as an effort elementary school teacher education program Faculty of Teacher Training and Education Jambi University facilitates students to learn.

This study produces four main recommendations: first, the attitude of the teacher candidate in pedagogic competence needs to be improved especially in pedagogic which need to be improved is the language ability which will be used by the teacher candidate as the language of instruction in every learning and become the communication tool in carrying out the learning. secondly, the motivation of a prospective teacher needs to be on guard as well as in the increase in learning either the motivation arising from the self-broked teacher or the external motivation that arises from the friends and lecturers. Third, the lecturer performance in the learning needs to be improved, especially in the selection of the learning models and the learning methods so that students who are learning do not feel bored with the learning given by the lecturers. Fourth, the education program of elementary school teachers faculty teacher and science education Jambi university needs to provide changes to the campus by providing decent facilities, especially in terms of facilitating Indonesian language laboratory with appropriate facilities, such as laboratory space, earphones, DVD, monitor, server, support language learning on writing, reading, speaking and listening materials.

Attitude enough students is a balanced attitude in the learning of physics because subjects are difficult to understand.

\section{Acknowledgements}

Thanks to all students of students at elementary school teacher education program, lecturer of Indonesian language and others who have helped in this research.

\section{References}

Adi, S.S. (2011). Communicative Language Teaching: Is it appropriate for Indonesian Context?. International Journal of Instructional Technology and Distance Learning, 81-88

Andayani. (2016). Improving the Language Skills and Local Cultural Understanding with Integrative Learning in Teaching Indonesian to Speakers of Other Languages (TISOL), International Journal of Language and Linguistics, 44-53

Andrini, V.S (2016). The Effectiveness of Inquiry Learning Method to Enhance Student's Learning Outcome : A Theoritical and Empirical Review. Journal of Education and Practice, 38-42

Çetin, A.Y. and Demiral, H .(2012).Evaluation Of Language and Literature Skills Of Secondary School Student In Turkey According To International Baccalaureate Diploma Program Criteria. International Journal of Instruction, 153-172.

Choi, J., Sazawa C. (2016). World Language Teachers Exploring Cultural Teaching Through Professional Learning Community. Electronic Journal of Foreign Teaching, 68-81.

Cohn, A., Ravindranath, M. (2014). Local Languages In Indonesia: Language Maintenance Or Language Shift?. Linguistik Indonesia, 131-148.

Creswell, J.W. 2009. Research Design Third Edition. University Of Nebraska Lincoln: SAGE Publication.

Haryanto, E. Sulistiyo,U. Khairani,M. Wulan, R. (2016). Indonesian Or English? EFL Student Teachers' Preference And Perception On The Language Use In The Classroom. Indonesia Journal of English Education. 46-59.

Ibrahim, J.(2001). The Implementation of EMI (English Medium Instruction) in Indonesian Universities: Its Opportunities, its Threats, its Problems, and its Possible Solutions. 121-137

Indrianti (2012). Developing Student- Centered Grammar Material for Beginners's Level Indonesian Electronic Journal of ForeignLanguage Teaching. 380-401.

Long, C, S., Ibrahim Z., Kowang, T.O. (2014). An Analysis on the Relationship between Lecturers' Competencies and Students' Satisfaction. International Education Studies, 38-46.

Ortlieb, E. (2013). Using Anticipatory Reading Guides to Improve Elementary Student's Comprehension. International Journal of Instruction, 145-162.

Paris., Said,I., Hamsa, A and Mahmudah. (2015). Discourse Mastery Based on Indonesian Language Teaching Skills of the 
Second Grade Students in Senior High School, Pangkep Regency. Journal of Language Teaching and Research, 172-178.

Republic of Indonesia. (2002). Law No. 20 of 2003 on National Education System. Jakarta: Ministry of Education

Republic of Indonesia. (2012). Law of the Republic of Indonesia Number 12 the Year 2012 on Higher Education. Indonesia:

Kemenristekdikti.

Samian, Y., \& Noor, N.M. (2012). Students' Perception on Good Lecturer Based on Lecturer Performance Assessment. Procedia-Social and Behavioral Science, 783-790. doi: 10.1016/j.sbspro.2012.09.716

Smith,N.J. (2009). Language Shift, Gender, and Ideologies of Modernity in Central Java, Indonesia. Journal of Linguistic Anthropology Association, 57-77

Watkins,C. dkk. (2002). Effective Learning. Institute of Education Universitas London: United Kingdom.

Widiani,M, dkk (2010). Teaching Competency Standars In Southeast Asian Contries. A Seameo Innotech Regional Education Project Series: Philippine.

Wong, C.C.Y, and Marlys, M.B. (2012). The Role Grammar in Communicative Language Teaching: An Exploration of Second Language Teacher's Perceptions and Classroom Practice. Electronic Journal of ForeignLanguage Teaching, 61-75.

Xiao, J. and Wilkins, S. (2015). The effects of lecturer commitment on student perceptions of teaching quality and student satisfaction in Chinese higher education. Journal of Higher Education Policy and Management, 37(1), 98-110. 